\title{
DETERMINATION OF FUTURE DESIGNERS' PROFESSIONALLY IMPORTANT COORDINATION QUALITIES
}

\author{
Chernovsky S. M., Kolumbet A. N.
}

Kiev National University of Technology and Design

\begin{abstract}
Purpose: to find out girl students' motor abilities, influencing to the largest extent on successfulness of designer's professional functioning. Material: 210 girl students of 18-22 years' age participated in experiment. Results: it was found that all indicators of future designers' professional qualities are closely connected with indicators of definite coordination abilities. High interconnection with kinesthetic indicators and girl students' professional skillfulness were noted. It was determined that quickness, concentration and re-switching of attention were closely connected with attention, operative memory, accuracy of reproduction of received information. Conclusions: for girl students-designers' successful professional progress it is necessary to develop kinesthetic, responding and orientation coordination qualities. These qualities are required for quick and effective solution of professional tasks, connected with accurate perception in the shortest possible time and keeping great volume of space information in memory.
\end{abstract}

Key words: students, designers, specialized physical education, professional-applied physical training.

\section{Introduction}

Scientific-technical progress and wide implementation of computer information technologies result in further intensification and complication of studying at HEE. More and more increasing volume of information to be perceived requires student's high psychological tension and physical efforts. Such transformation of functioning can not but reflect in specific features of adaptation processes and health condition of people, dealing with mental work and spending much time with computer.

Formation of future designers' professional qualities in technical HEE is one of the most important tasks. The process of specialist's training at HEE includes a number of pedagogic aspects. They include professionalapplied physical training. At HEE discipline "Physical education" contains such part as professional-applied physical training. But this part does not have clear, scientifically substantiated methodic instructions on organization of trainings of different specializations students. Besides, there is no software maintenance of this part.

It should be noted that the problem of formation of motor skills and abilities in professional training is connected with condition of certain coordination mechanisms. The basis of professional training is control and assessment of motor system's condition and its sub-systems [3, 8, 13, 14, 17, and 23]. This is really existing problem and it is connected with working out of effective methodic of physical education teaching, considering future professional functioning. Its solution in educational process is closely connected with physical trainings of girl students-designers. In these trainings development of basic coordination qualities, which are the basis for further formation of professionally important coordination qualities, take place.

Training of coordination qualities have always been paid great attention. The works of a number of authors are devoted to perfection of youth's coordination qualities [4, 7, 11, 12, and 20]. Some works elucidate professional-applied physical training of technical HEEs' students [8, 10, 16, 21, and 22]. However, there are quite a few researches, devoted to specialized physical training of designers [1]. It proves the importance of this problem.

Purpose, tasks of the work, material and methods

The purpose of the work is to find out girl students' motor abilities, influencing to the largest extent on successfulness of designer's professional functioning.

The methods and organization of the research: 210 girl students of 18-22 years' age from Kiev technical HEE were tested.

Results were received with usage of methodic and with the help of motor-coordination analyzer ADKR2. This device is a plate, on which there are four carved tracks of different configuration (every track of $450 \mathrm{~mm}$ length). At the beginning and at the end of each track there are special contacts. Electric probe touches these

(c) Chernovsky S. M., Kolumbet A. N., 2016

doi:10.15561/20755279.2016.0206 
contacts in initial position and at the end of task. In response to light bulb $(0.45 \mathrm{~W})$ ignition the tested, trying not to touch walls, shall move probe from the beginning to the end of track. Before test instructions were given. These instructions were repeated in the course of movement: do quicker, not neglecting accuracy in favor of speed. Considering high scope of tests, light irritators were given to every tested with interval of 10-15 sec. It excluded influence of previous reaction. Before testing, short training in the form of simple measurements of the tested time parameters, was carried out with each tested. With multiple repetitions variation of indicators reduced and stabilized.

The level of girl students' accuracy was assessed with the help of the following tests: 1) accuracy of reproduction of pre-set effort value was determined with hand dynamometer; 2) accuracy of reproduction of preset amplitude of arms' movements was determined with kinematic meter of M.I. Zhukovskiy.

Responding qualities were registered with the following tests: 1) for quickness of reaction (test "Catching rule" [6]); 2) test for reaction to moving object. For this test computer program "Prognoz", worked out by Institute of physiology, named after A.A. Bogomolets of AS of Ukraine, Kiev; 3) test for quickness of visual-motor reaction (simple and complex) with computer program "Prognoz"; 4) Test for quickness of reaction ("Catching stick" 1]); 5) complex coordination test for determination of multidirectional speed-power movements per definite time (computer program "Prognoz".

Orientation in space was assessed with the help of test "Labyrinth" [5].

Assessment of girl students-designers' professionally important abilities was conducted with the following tests: 1) distribution of attention (test "Finding of numbers" [15]); 2) scope of mechanic memorizing (test "Quantity of men figures" [15]); 3) distribution of attention and quickness of operative thinking (test "Assembly of puzzles for definite time" [1]); 4) quickness of operative thinking (Koss's cubes" [2]); 5) quickness, re-switching and concentration of attention and accuracy of task's fulfillment were registered with special device [9].

Static balance was studied with Romberg's test (posture of "Stork"); 2) dynamic balance was assessed with test "Turns on gymnastic bench" [18].

\section{Results of the research}

Having fulfilled multiple correlation analysis we built correlation matrix. In this matrix information was analyzed, considering character, quantity and density of the received correlations. Attention was paid only to statistically significant indicators. It was found that all indicators of future designers' professional qualities were interconnected with indicators of definite coordination abilities. Alongside with it, the conducted analysis showed ambiguous character of correlations by different kinds of future designers' professional qualities.

Correlation analysis showed dependence of attention distribution indicator on indicator of orientation in space, quickly and accurately fulfill task. In this case correlation coefficient was 0.67 . It reflects moderate correlation of the tested indicators. It should be noted that in test "Labyrinth" time and accuracy of task's fulfillment were assessed. In the same way, when fulfilling test "Finding numbers" time and attention were assessed. Activity of such character takes place in professional functioning of designers (for example when making fine and precise movements with brush, when preparing markup and drawing).

In table 1 we present analysis of parameters' correlation matrix. These parameters show dependence of indicator "Quantity of men figures" on indicators of tests "Labyrinth", complex visual motor reaction, "Catching rule". Analysis of test "Quantity of men figures" correlation with indicators of tests for responding (orientation and kinesthetic qualities) permits to think that development of coordination facilitates progress of professional skills. Degree of density of the tested parameters was moderate. It is witnessed by correlation coefficients $(0.61$ $0.77)$.

The determined character of correlations witnesses about significance of responding, orientation and kinesthetic qualities of girl students. These qualities are required for quick and effective solution of professional tasks, connected with accurate perception in the shortest time and keeping great volume of space and other information in memory.

One of the most important disciplines at design faculty is "Painting". When assessing progress in this subject the following moments are considered: naturalistic level of drawing (observance of volume, plan; presence of fine details); proportionality of figure in the picture; correctness of composition; fulfillment of sketch by lines 
or by spot with the help of fine and thick brushes. Analysis of progress in their professional discipline "Painting" correlation with indicator of test "Reproduction of pre-set amplitude of arm's movement" showed moderate degree of the tested parameters' density (correlation coefficient was 0.61 ).

Table 1. Correlations of indicator, reflecting attention, operative memory, quickness of memorizing and accuracy of the received information reproduction with indicators of orientation, responding and kinesthetic qualities

\begin{tabular}{lc}
\hline Indicators & Correlation coefficient \\
\hline Orientation ability (accuracy of reproduction of pre-set movement's trajectory, test & 0.61 \\
"Labyrinth") & 0.72 \\
Responding ability (test CVMR) & 0.64 \\
Responding ability (test "Catching rule") & 0.63 \\
Responding ability (test "Catching stick") & 0.68 \\
Responding ability (test SVMR) & 0.74 \\
Responding ability (reaction to moving object) & 0.77 \\
Distribution of attention (test "Finding numbers") & 0.68 \\
Dynamic balance & 0.63 \\
Static balance & 0.72 \\
Complex coordination test &
\end{tabular}

Notes: CVMR - complex visual motor reaction; SVMR - simple visual motor reaction.

In discipline "Drawing" ability to build objects, to model volume; quality of shading, ability to locate drawing on paper correctly are assessed. Drawings are fulfilled by pencils and other soft materials (for example with coal). These materials are very fragile. That is why it is necessary to feel arms' pressure on them. We analyzed indicators of progress in discipline "Drawing". This analysis showed dependence with indicators of kinesthetic qualities and ability of orientation in space. Density of correlations was moderate (0.61-0.77). It witnesses that it is important to perfect girl students' basic kinesthetic and orientation, coordination qualities for their future professional functioning.

We also determined correlation of test "Assembly of puzzles" (which reflects fine motor abilities of working arm) with indicators of test "Koss's cubes" (quickness of operative thinking, ability to constructive praxis). Degree of density of the tested parameters was moderate (0.75). Test for quickness of operative thinking is a complex one. It reflects development of girl students' moor skills and shows component of mental processes (ability to observe composition: presence of composition center, ability to distinguish tints, to reproduce shape of the depicted object), which is rather important for future designers. It witnesses that it is necessary to improve girl students' coordination: ability to constructive praxis, quickness of operative thinking, ability to quickly and accurately react to the received task and fulfill it exactly in compliance with the set purpose.

General level of girl students-designers was determined with points. These points reflected relation of accuracy of standard drawing fulfillment to time of its fulfillment. Correlation analysis showed interconnection of this indicator with indicators of kinesthetic and responding qualities (test "Reaction to moving object"); test "Reproduction of pre-set amplitude of arm's movements"). Analysis of the found dependences' character (between assessment points and kinesthetic level) witnesses about presence of expressed correlation (correlation coefficient was 0.80). Correlation of indicator of girl students' professionalism with indicator of responding qualities (test "Reaction to moving object") can be estimated as moderate. Correlation coefficient was 0.62.

In table 2 we render analysis of parameters' correlation matrix. This analysis opens dependence of indicator of attention re-switching and concentration and accuracy of task's fulfillment (test "Balls) on indicator of other tests. Analysis of indicators' correlation in test "Balls" with development of responding, orientation and kinesthetic qualities showed their influence on progress of professional skills. Parameters' density was moderate and high (correlation coefficients were 0.55-0.86).

Thus, correlation analysis of girl students-designers' professional qualities and indicators of coordination qualities showed at their close interaction. 


\section{Discussion}

Results of our experiments proved the works of other authors about training of professional qualities by physical education means [19, 24-28].

The fulfilled researches continue the series of experiments on professional (specialized) physical training of students. If earlier we tested girl students of Ukrainian pedagogic HEEs, then in our present works girl students of technical HEEs participated.

It was found that by most of indicators characteristic of the tested indicators is nearly equal. Differences concern only professional skills (different tests, assessment scales and parameters). Varying of correlation coefficients $( \pm 5.0)$ is not significant.

Table 2. Correlations of indicator, which characterizes quickness of attention re-switching, attention concentration and accuracy of fulfillment (test "Balls"), with indicators of orientation, responding and kinesthetic qualities

\begin{tabular}{ll}
\hline Indicators & Correlation coefficient \\
\hline Responding ability (test CVMR) & 0.76 \\
Responding ability (test “Catching rule") & 0.85 \\
Responding ability (test "Catching stick") & 0.86 \\
Responding ability (test SVMR) & 0.79 \\
Responding ability (reaction to moving object) & 0.82 \\
Distribution of attention (test "Finding numbers") & 0.63 \\
Dynamic balance & 0.58 \\
Static balance & 0.55 \\
Scope of mechanical memorizing (test "Quantity of men figures") & 0.67 \\
Distribution of attention and quickness of operative thinking (test "Assembly of & 0.77 \\
puzzles") & \\
Quickness of operative thinking (test "Koss's cubes") & 0.69 \\
Accuracy of reproduction of pre-set effort & 0.75 \\
Accuracy of reproduction of pre-set movement's amplitude & 0.74 \\
\hline
\end{tabular}

Notes: CVMR - complex visual motor reaction; SVMR - simple visual motor reaction.

Further researches will be devoted to testing of future economists, engineers of light industry, future pharmacists and chemists.

\section{Conclusions}

The data, received in correlation analysis permit to make the following conclusions:

1) For successful professional progress of girl students-designers it is necessary to train mainly kinesthetic, responding and orientation coordination qualities. However, correlations were found not with all kinds of coordination qualities. We did not find correlation of professional skills and ability to keep static balance. It can be explained by the fact that it is well developed and is habitual for the girl students. But keeping one posture in work (for example standing at easel or sitting at computer) is very difficult.

2) When working out program maintenance for professional-applied physical training it is necessary to pay attention exactly to perfection of the above listed coordination qualities. It is still more important that the fulfilled correlation analysis of kinesthetic, responding and orientation qualities showed negative dynamic in period from $1^{\text {st }}$ to $4^{\text {th }}$ year of study. Already in $1^{\text {st }}$ year girl students-designers test indicators were lower average age standards ("Catching of vertically falling object", "Reaction to moving object", complex coordination test).

3) Pedagogic influence shall be started from the $1^{\text {st }}$ year. Then, by the graduation girl students-designers will acquire required professionally important skills and abilities to the highest extent.

\section{Acknowledgements}

The work has been fulfilled in compliance with topical plan and general problem of scientific researches of physical education and health department of Kiev national university of technology and design "Socialpedagogic aspects of healthy life style formation in students by physical education means". The work is a part of scientific direction of researches of physical education and martial arts department of physical education and sports 
Faculty of National pedagogic university, named after M.P. Dragomanov “4.6.3.1. "Formation of youth's physical perfection in educational system".

\section{Conflict of interests}

The authors declare that there is no conflict of interests.

\section{References:}

1. Afanas'eva IV. Metodika sovershenstvovaniia professional'no znachimykh koordinacionnykh sposobnostej $u$ budushchikh specialistov dizajnerov. Cand. Diss. [Methodic of perfection of professionally important coordination abilities of future specialists-designers. Cand. Diss.]: Omsk; 2008. (in Russian)

2. Burlachuk LF. Psikhodiagnostika [Psycho-diagnostic], Sankt Petersburg: Peter; 2006. (in Russian)

3. Vilenskij MIa, Il'inich VI. Fizicheskaia kul'tura rabotnikov umstvennogo truda [Physical culture for mental workers], Moscow: Knowledge; 1987. (in Russian)

4. Vilenskij MIa, Safin MIa. Professional'naia napravlennost' fizicheskogo vospitaniia studentov pedagogicheskikh special'nostej [Professional orientation of pedagogic specialties' students' physical education], Moscow: High school; 1989. (in Russian)

5. Gorskaia IIu, Suiangulova LA. Bazovye koordinacionnye sposobnosti shkol'nikov s razlichnym urovnem zdorov'ia [Basic coordination abilities of schoolchildren with different level of health], Omsk: SibGUFK; 2000. (in Russian)

6. Dushanin SA. Bal'naia sistema kompleksnogo vrachebno-pedagogicheskogo kontrolia na zaniatiiakh massovymi formami fizicheskoj kul'tury [Points' system of complex medical-pedagogic control at classes of mass forms of physical culture]. Teoriia i praktika fizicheskoj kul'tury 1978;4:49-52. (in Russian)

7. Il'inich VI, Golovina VA, Masliakova VA, Korobkova AV. Professional'no-prikladnaia fizicheskaia podgotovka [Professional-applied physical training], Moscow: High school; 1983. (in Russian)

8. Kabachkov VA, Polievskij SA. Razrabotka professional'no-prikladnoj fizicheskoj podgotovki i opyt ee vnedreniia $\mathrm{v}$ uchebnykh zavedeniiakh proftekhobrazovaniia [Development of professional-applied physical training and experience of its implementation in vocational education establishments]. Teoriia $i$ praktika fizicheskoj kul'tury, 1980;7;30-34. (in Russian)

9. Kirichenko SI. Professional'no-prikladnaia fizicheskaia podgotovka studentov ekonomicheskogo fakul'teta. Cand. Diss. [Professional-applied physical training of economic faculty students. and. Diss.], Maikop; 1998. (in Russian)

10. Kolumbet OM. Psikhofizichni osoblivosti trudovoi diial'nosti vchiteliv-naochnikiv [Psycho-physical characteristics of work of teachers, using visual aids]. Pedagogics, psychology, medical-biological problems of physical training and sports 2012;8:48-53. (in Ukrainian)

11. Kolumbet OM. Rozvitok koordinacijnikh zdibnostej molodi [Development of youth's coordination abilities], Kiev: Education; 2014. (in Ukrainian)

12. Kolumbet A.N. Influence of stimulated plasticity training method on coordination indicators of high pedagogic educational estableshments' girl students. Physical Education of Students, 2015;6:31-37. http://dx.doi.org/10.15561/20755279.2015.0604

13. Korobejnikov GV. Psikhofiziologicheskie mekhanizmy umstvennoj deiatel'nosti cheloveka [Psychophysiological mechanisms of human mental functioning], Kiev; 2002. (in Russian)

14. Korovin SS. Teoreticheskie i metodologicheskie osnovy professional'noj fizicheskoj kul'tury uchashchejsia molodezhi [Theoretical and methodological principles of students' professional physical culture], Moscow: VNIIFK; 1997. (in Russian)

15. Sizanov AN. Testy i psikhologicheskie igry [Tests and psychological games], Minsk; 2008. (in Russian)

16. Raevskij RT. Professional'no-prikladnaia fizicheskaia podgotovka studentov tekhnicheskikh vuzov [Professional-applied physical training of technical HEEs' students], Moscow: High school; 1989. (in Russian)

17. Gorelov AA, Kondakov VL, Usatov AN. To the question about the use of independent physical training in educational space of modern higher institute. Physical Education of Students, 2013;1:17-26. http://dx.doi.org/10.6084/m9.figshare.156351

18. Hirtz P. Koordinative Fahigkeiten im Schulsport [Coordinative abilities in school sports], Berlin: Volk und 
Wissen, Volksseigener Verlag; 1985. (in German)

19. Khripunova LD. To the question of the formation of personal qualities of future doctors by means of combat sports. Physical Education of Students, 2014;5:43-47. http://dx.doi.org/10.15561/20755279.2014.0508

20. Kolumbet AN. Physical education for the students of pedagogical specialities. III international research and practice conference Science "Technology and Higher Education”, Westwood, Canada. 2014. P. 34-42.

21. Kolumbet AN. Development of coordination abilities of young people. Vinternational research and practice conference "Science and Education", Munich, Germany. 2014. P. 54-62.

22. Kondakov VL, Kopeikina EN, Balysheva NV, Usatov AN, Skrug DA. Causes of declining interest of students to employment physical education and sports. Physical education of students, 2015;1:22-30. http://dx.doi.org/10.15561/20755279.2015.0104

23. Korobeynikov G. Psychophysiological Peculiarities of Sexual Dimorphism in Athletes. Psychologe Research, 2012;2(6):336-342.

24. Otravenko OV. Formation of student personality's physical culture as subject of professional functioning. Physical Education of Students, 2015;6:50-55. http://dx.doi.org/10.15561/20755279.2015.0607

25. Pichurin VV. Resilience of students and their readiness for professional functioning. Physical Education of Students, 2015;3:38-43. http://dx.doi.org/10.15561/20755279.2015.0305

26. Radchenko AV. Professional self-assessment of future health basics teachers as professionally important quality. Pedagogics, psychology, medical-biological problems of physical training and sports, 2015;12:8790. http://dx.doi.org/10.15561/18189172.2015.12013

27. Stepanchenko NI. Structure and state of the university of physical culture students' professional-pedagogical motivation. Pedagogics, psychology, medical-biological problems of physical training and sports, 2013;3:62-68. http://dx.doi.org/10.6084/m9.figshare.644799

28. Voitovska ON. Computer diagnostics of level of professional competence formation of future physical culture teachers in the biological disciplines study. Pedagogics, psychology, medical-biological problems of physical training and sports, 2013;3: 11-17. http://dx.doi.org/10.6084/m9.figshare.644905 


\section{Information about the authors:}

Chernovsky S.M.; http://orcid.org/0000-0002-1927-9203; chernovskij.sm@knutd.com.ua; Kiev National University of Technology and Design; st. Nemirovich-Danchenko, 2, Kiev, 14013, Ukraine.

Kolumbet A.N.; http://orcid.org/0000-0001-8775-4232; re_play@3g.ua; Kiev National University of Technology and Design; st. Nemirovich-Danchenko, 2, Kiev, 14013, Ukraine.

Cite this article as: Chernovsky S.M., Kolumbet A.N. Determination of future designers' professionally important coordination qualities. Physical education of students, 2016;2:38-44. doi:10.15561/20755279.2016.0206

The electronic version of this article is the complete one and can be found online at: http://www.sportpedu.org.ua/html/arhive-e.html

This is an Open Access article distributed under the terms of the Creative Commons Attribution License, which permits unrestricted use, distribution, and reproduction in any medium, provided the original work is properly cited (http://creativecommons.org/licenses/by/4.0/deed.en).

Received: 03.03.2016

Accepted: 21.03.2016; Published: 25.04.2016 